\title{
Investigating Temporal Variation of Water Quality and Benthic Macroinvertebrates in Taudaha Lake, Kathmandu, Nepal
}

\author{
Sagar Shrestha ${ }^{*}$, Puspa L. Adhikari² \\ ${ }^{1}$ Department of Physical and Environmental and Sciences, Texas A\&M University-Corpus Christi, Corpus Christi, TX, USA \\ ${ }^{2}$ Department of Environmental Sciences, Louisiana State University, Baton Rouge, LA, USA \\ Email: *sshrestha1@islander.tamucc.edu
}

How to cite this paper: Shrestha, S. and Adhikari, P.L. (2016) Investigating Temporal Variation of Water Quality and Benthic Macroinvertebrates in Taudaha Lake, Kathmandu, Nepal. Journal of Water Resource and Protection, 8, 1283-1296.

http://dx.doi.org/10.4236/jwarp.2016.813098

Received: November 8, 2016

Accepted: December 12, 2016

Published: December 15, 2016

Copyright (c) 2016 by authors and Scientific Research Publishing Inc. This work is licensed under the Creative Commons Attribution International License (CC BY 4.0).

http://creativecommons.org/licenses/by/4.0/

\begin{abstract}
Taudaha Lake is one of the important wetlands in Nepal, as it provides critical habitats for thousands of migratory birds and fishes. Despite being a critically important water body, there is a lack of detail chemical and biological studies on this lake. The present study investigates the effects of seasonal water quality variations in distribution and abundance of macroinvertebrates in Taudaha Lake, during four different seasons in 2006. The results indicate that all the water quality parameters, except secchi depth, and total alkalinity, significantly varied among seasons. The gross primary productivity of the lake also significantly varied among the seasons, with highest primary production during summer $\left(3.92 \pm 0.18 \mathrm{gC} / \mathrm{m}^{3} /\right.$ day $)$ and lowest during spring $\left(2.44 \pm 0.67 \mathrm{gC} / \mathrm{m}^{3} /\right.$ day $)$. A total of 2166 individual benthic macroinvertebrates from 10 families and 7 orders were collected during the study period. Unlike water quality parameters, the macroinvertebrate species composition did not vary significantly among the seasons. The results suggested that the change in lake water quality did not have significant impacts on community metrics such as species diversity, species richness, and species evenness.
\end{abstract}

\section{Keywords}

Taudaha, Lake, Water Quality, Macroinvertebrates, Productivity

\section{Introduction}

Lakes and ponds cover $2-2.8 \times 10^{6} \mathrm{~km}^{2}$ or $1.3 \%-1.8 \%$ of earth's non-oceanic area [1] [2]. Only a few large lakes contribute to the total global lake area, as most of the world's lakes are dominated by small lakes [2] [3]. The lakes and ponds are important compo- 
nents of the freshwater ecosystems and play a significant role in the distribution of vital living species in the earth [4]. Water quality and biological monitoring of the lakes and ponds has become critical with an increase in adverse anthropogenic impacts on these water bodies [5]. Land use changes such as agriculture and urban development are important factors affecting the water quality [6] and the biological communities of the lakes [7]. Macroinvertebrates are the important biological indicators of water pollution which are directly affected by physical and chemical alteration of the lake water and habitat conditions [7] [8]. Understanding the abundance and community structure of the macroinvertebrates provides important information on the condition of the water quality and the overall health of the lake ecosystems [9]. Species of order Ephemeroptera, Plecoptera, and Trichoptera (EPT) have been commonly used as indicators of healthy lakes [10], whereas species of Diptera and Oligochaeta provide useful information about the pollution of a lake [9] [11].

Kathmandu, the capital city of Nepal, is probably one of the rapidly urbanized cities among the developing nations. Alarming population growth in last few decades has created immense pressures in the natural water bodies in and around the city. The major rivers flowing through the Kathmandu valley is heavily polluted due to the mixing of untreated sewage in the rivers [12]. In absence of effective regulation on municipal wastewater treatment, the city discharges a tremendous amount of nutrient rich organic waste into the major water bodies [13]. The rainwater runoff from the highly urbanized watershed further adds pollutants into the river and lakes in the valley [12]. Controlling water pollution and restoring water bodies back to their natural stages are the major challenge for national and international organizations working in this area. However, this region lacks the vital background information on water quality parameters of the major water bodies, which is essential in order to implement such actions.

Taudaha Lake is situated in the suburb of the Kathmandu district, which is relatively less polluted in comparison to the major water bodies in the urban settings. The lake provides an important habitat and refuge for migratory birds and different species of fish and supports the local business through eco-tourism. Even though the first scientific study of the Taudaha Lake was conducted in 1973 [14], very few researches on the effect of water quality on the benthic macroinvertebrates have been conducted. The study conducted during 1973 represents the time before the beginning of the major urbanization in the city and is not representative of the lake biogeochemistry of posturbanization era. Furthermore, there is limited information on the effect of water quality to the benthic macroinvertebrates.

The major objective of the present study is to characterize water quality, and to study the seasonal effect of water quality on the abundance and distribution of benthic macroinvertebrates in Taudaha Lake. The proximity of the Lake to highly urbanized Kathmandu metropolitan city and its ecological and economical significance make it an ideal location for such study. The information on the distribution and abundance of macroinvertebrates in the Taudaha Lake will provide invaluable information for controlling/reducing water pollution, eutrophication and the actions on restoring water 
bodies in the city.

\section{Methods}

\subsection{Study Area}

The study was conducted in Taudaha Lake, situated $6 \mathrm{~km}$ southeast of Kathmandu district $\left(27^{\circ} 38^{\prime} 55^{\prime \prime} \mathrm{N} 85^{\circ} 16^{\prime} 54^{\prime \prime} \mathrm{E}\right)$. Taudaha Lake occupies an area of 4 ha with a maximum depth of $6 \mathrm{~m}$, receiving the water via surface and sub-surface runoffs (Figure 1). Several inlets exist around the lake, but two surface inlets are major sources of water in the lake, especially during the monsoon. The lake also receives a discharge from the surrounding croplands, especially during the irrigation and wet seasons. The general sampling for this study entailed that lake water quality and benthic macroinvertebrates were monitored in six sites during winter, spring, summer, and autumn seasons of 2006.

\subsection{Water Quality Monitoring}

Water quality parameters were measured from all sites during samplings seasons. Water temperature $\left({ }^{\circ} \mathrm{C}\right), \mathrm{pH}$ (standard units), secchi depth $(\mathrm{cm})$ and conductivity $(\mu \mathrm{S} / \mathrm{cm})$ were measured in situ. Dissolved oxygen ( $\mathrm{DO} ; \mathrm{mg} / \mathrm{L}$ ) was determined in the field

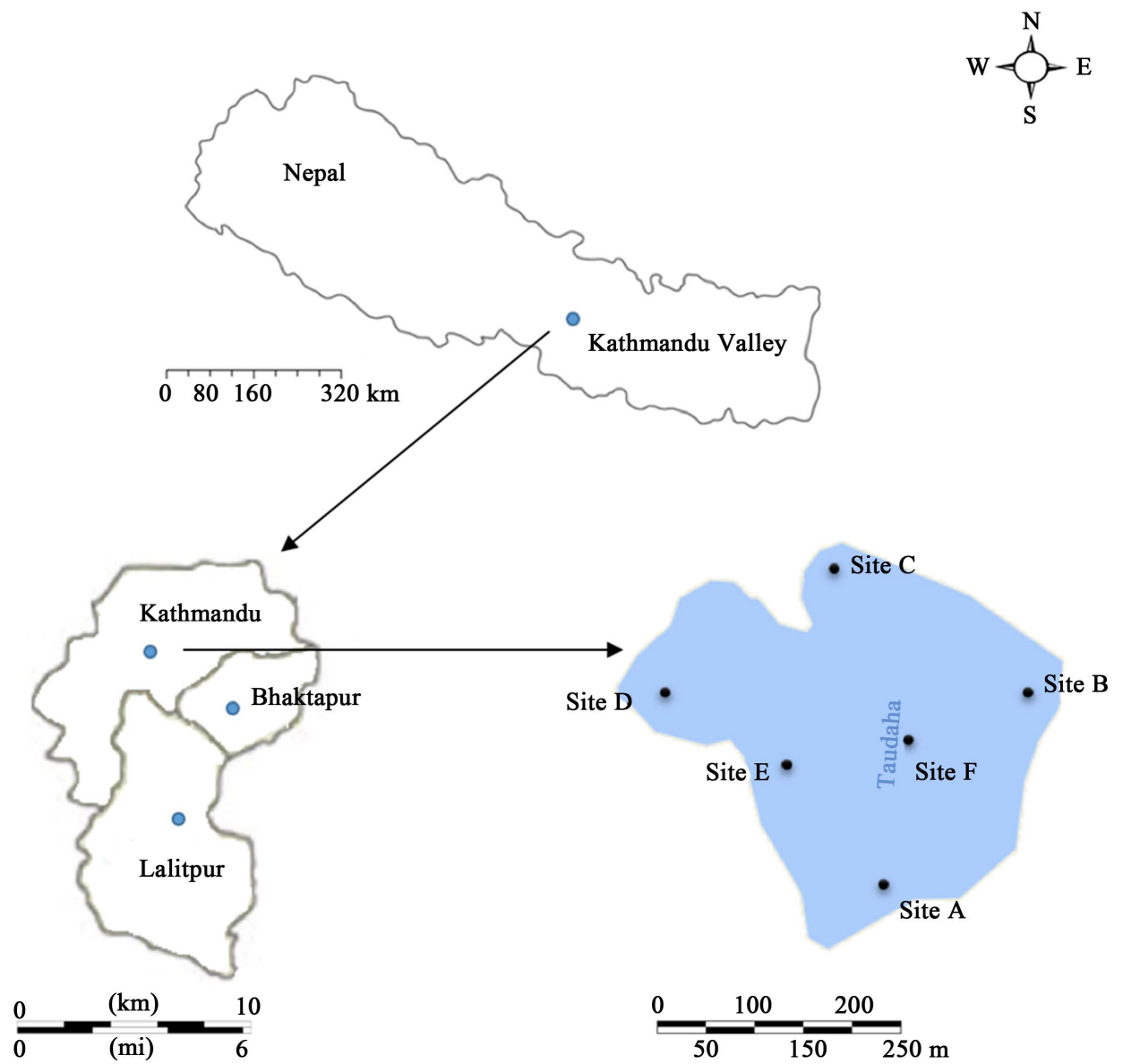

Figure 1. Location map of Taudaha Lake with six sampling stations. 
immediately after sample collection using Winkler method [13]. Water samples for the analysis of chloride, carbon dioxide, alkalinity, hardness, nitrate, phosphate, and primary productivity, were collected in 1-L acid-washed plastic bottles, transported on ice and stored at $-4^{\circ} \mathrm{C}$ until lab analysis. Chloride $(\mathrm{mg} / \mathrm{L})$, free carbon dioxide $\left(\mathrm{CO}_{2} ; \mathrm{mg} / \mathrm{L}\right)$, total alkalinity $\left(\mathrm{mg} / \mathrm{L}\right.$ as $\left.\mathrm{CaCO}_{3}\right)$, total hardness $\left(\mathrm{mg} / \mathrm{L}\right.$ as $\left.\mathrm{CaCO}_{3}\right)$, nitrate $(\mathrm{mg} / \mathrm{L})$, and phosphate $(\mathrm{mg} / \mathrm{L})$ were determined following standard methods [15]. The net primary productivity and gross primary productivity were measured using light, dark bottle methods, while DO concentration from these light and dark bottles were measured using Winkler method.

\subsection{Macroinvertebrate Monitoring}

Samples for qualitative and quantitative analysis of macroinvertebrate were collected using a Van-Veen grab sampler $\left(250 \mathrm{~cm}^{2}\right)$. The grab sampler was used in all six sites during the sampling period. Macroinvertebrates were identified to family level using appropriate taxonomic keys [16]. Total abundances were expressed as the number of macroinvertebrates collected within each $250 \mathrm{~cm}^{2}$ of all sites during the four seasons. The data were also used to compute Shannon diversity index $(H)$ [17], Species evenness index $(E)$ [18], and Species richness index $(D)$ [19] for each sampling event. These three standard indices for each sampling events were calculated using following formula:

Shannon diversity indices $\left(H^{\prime}\right)$ :

$$
H^{\prime}=-\sum_{i=1}^{s}\left(\frac{n_{i}}{N}\right) \ln \left(\frac{n_{i}}{N}\right)
$$

where, $n_{i}=$ number of individuals of species $i, N=$ total number of individuals in the sample, and $s=$ number of species represented in the sample

Species evenness index $(E)$ :

$$
E=\frac{H^{\prime}}{H_{\max }^{\prime}}
$$

where, $H^{\prime}=$ Shannon diversity index value, $H_{\max }^{\prime}=$ theoretical maximum possible diversity $=\ln (\mathrm{S})$, and $S=$ number of different species in the sample

Species richness index $(D)$ :

$$
D=\frac{S}{\sqrt{N}}
$$

where, $S=$ number of different species in the sample, $N=$ total number of individuals in the sample.

\subsection{Data Analysis}

We used one-way analysis of variance (ANOVA) to compare water quality, primary productivity, and macroinvertebrate community parameters among the sampling seasons. This analysis was used to test for the effects of time (i.e. seasons) on water quality, primary productivity, and macroinvertebrate community metrics. Significance for all 
statistical analysis was assessed at $\alpha=0.05$. The statistical analysis was conducted using the Statistical Analysis Software (SAS, version 9.2, Cary, North Carolina, USA).

\section{Results}

\subsection{Water Quality Parameters}

All the water quality parameters, except secchi depth and total alkalinity, varied significantly among the sampling seasons (Table 1 ). The water temperature of the lake varied between $17.3^{\circ} \mathrm{C}$ to $22^{\circ} \mathrm{C}$ throughout the study period, with an annual average temperature of $19.4^{\circ} \mathrm{C} \pm 2^{\circ} \mathrm{C}$. As expected, water temperature varied significantly $(P<0.001)$ with seasons, with the maximum during summer $\left(22.0^{\circ} \mathrm{C} \pm 0.5^{\circ} \mathrm{C}\right)$ and minimum during winter $\left(17.3^{\circ} \mathrm{C} \pm 1.1^{\circ} \mathrm{C}\right.$ ) (Table 1; Figure 2(a)). The average annual $\mathrm{pH}$ of the lake was recorded as $7.65 \pm 0.4$. The $\mathrm{pH}$ of the lake varied significantly $(P<0.001)$ among the sampling seasons, with the maximum $\mathrm{pH}(8.02 \pm 0.21)$ during summer and minimum (7.08 \pm 0.22 ) during autumn (Table 1; Figure 2(b)). The average conductivity of the lake was recorded as $273 \pm 24.2 \mu \mathrm{S} / \mathrm{cm}$, with the maximum in summer $(291 \pm 2.61$ $\mu \mathrm{S} / \mathrm{cm})$ and minimum in autumn $(238 \pm 4.3 \mu \mathrm{S} / \mathrm{cm})$. The conductivity was significantly different among the seasons $(P<0.001)$ (Table 1$)$. The average secchi depth was recorded as $52.33 \pm 3.4 \mathrm{~cm}$ over a year. The highest secchi depth was observed during autumn $(55.75 \pm 5.38 \mathrm{~cm})$ and the lowest secchi depth was observed during spring (48.42 $\pm 8.0 \mathrm{~cm})$. The secchi depth did not showed the significant differences among the seasons $(P=0.25)$ (Table 1; Figure 2(c)).

Table 1. One-way analysis of water quality (mean \pm SD) parameters of Taudaha Lake, Kathmandu, Nepal during four seasons of 2006.

\begin{tabular}{|c|c|c|c|c|c|c|c|}
\hline \multirow{2}{*}{ Parameters } & \multicolumn{7}{|c|}{ Seasons } \\
\hline & Winter & Spring & Summer & Autumn & Average & $\mathbf{F}$ & $P$ \\
\hline $\mathrm{pH}$ & $7.75 \pm 0.23$ & $7.75 \pm 0.10$ & $8.02 \pm 0.21$ & $7.08 \pm 0.22$ & $7.65 \pm 0.4$ & 23.9 & $<0.001$ \\
\hline Temperature $\left({ }^{\circ} \mathrm{C}\right)$ & $17.33 \pm 1.11$ & $19.15 \pm 0.31$ & $22.05 \pm 0.53$ & $18.95 \pm 0.52$ & $19.37 \pm 2$ & 48.66 & $<0.001$ \\
\hline Conductivity $(\mu \mathrm{S} / \mathrm{cm})$ & $275.17 \pm 2.93$ & $288 \pm 4.05$ & $291 \pm 2.61$ & $238.33 \pm 4.32$ & $273 \pm 24.2$ & 278.45 & $<0.001$ \\
\hline Secchi depth $(\mathrm{cm})$ & $50.67 \pm 9.01$ & $48.42 \pm 8.04$ & $54.5 \pm 3.39$ & $55.75 \pm 5.38$ & $52.33 \pm 3.4$ & 1.48 & 0.249 \\
\hline Chloride (mg/L) & $21.06 \pm 2.76$ & $23.07 \pm 1.60$ & $25.56 \pm 2.25$ & $31.68 \pm 5.21$ & $25.35 \pm 4.60$ & 12.04 & $<0.001$ \\
\hline Free $\mathrm{CO}_{2}(\mathrm{mg} / \mathrm{L})$ & $16.57 \pm 1.71$ & $16.68 \pm 5.27$ & $5.79 \pm 1.01$ & $18.47 \pm 3.27$ & $14.38 \pm 5.8$ & 18.95 & $<0.001$ \\
\hline Total alkalinity $\left(\mathrm{mg} / \mathrm{L}\right.$ as $\left.\mathrm{CaCO}_{3}\right)$ & $168.33 \pm 6.06$ & $170.42 \pm 6.21$ & $160 \pm 8.94$ & $161.48 \pm 4.91$ & $165.06 \pm 5.1$ & 3.47 & 0.354 \\
\hline Total hardness (mg/L as $\left.\mathrm{CaCO}_{3}\right)$ & $124 \pm 4.00$ & $138.5 \pm 4.64$ & $131.17 \pm 3.13$ & $96.27 \pm 3.85$ & $122.48 \pm 18.45$ & 131.65 & $<0.001$ \\
\hline $\mathrm{DO}(\mathrm{mg} / \mathrm{L})$ & $10.11 \pm 0.37$ & $4.96 \pm 0.51$ & $8.89 \pm 0.87$ & $5.27 \pm 0.59$ & $7.31 \pm 2.6$ & 106.1 & $<0.001$ \\
\hline Nitrate (mg/L) & $0.03 \pm 0.009$ & $0.05 \pm 0.004$ & $0.06 \pm 0.008$ & $0.04 \pm 0.015$ & $0.05 \pm 0.01$ & 6.05 & 0.004 \\
\hline Phosphate (mg/L) & $0.05 \pm 0.002$ & $0.13 \pm 0.06$ & $0.12 \pm 0.009$ & $0.12 \pm 0.072$ & $0.10 \pm 0.04$ & 3.99 & 0.022 \\
\hline Gross productivity (gC/M ${ }^{3} /$ day) & $3.16 \pm 0.75$ & $2.44 \pm 0.67$ & $3.92 \pm 0.18$ & $3.13 \pm 2.01$ & $3.16 \pm 0.6$ & 6.5 & 0.003 \\
\hline Net productivity (gC/M $\mathrm{M}^{3} /$ day) & $1.71 \pm 0.38$ & $1.55 \pm 0.78$ & $1.58 \pm 0.17$ & $2.01 \pm 0.39$ & $1.71 \pm 0.21$ & 1.12 & 0.364 \\
\hline
\end{tabular}

Significant ANOVA effects $(P \leq 0.05)$ are indicated with bold. 


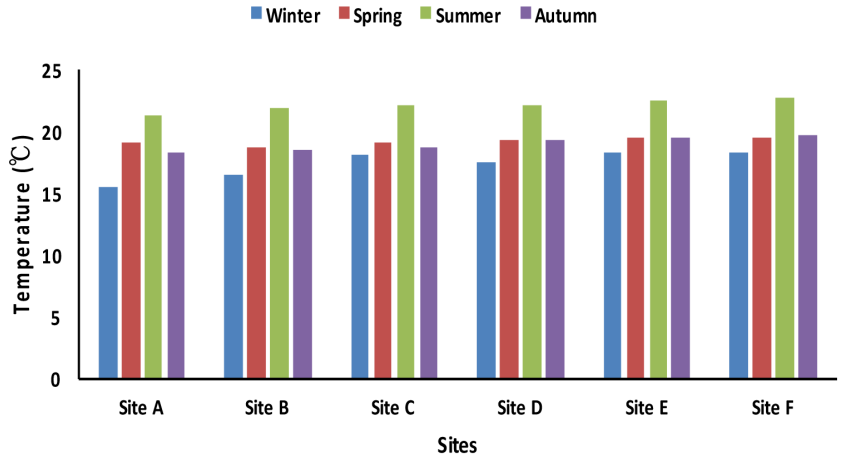

(a)

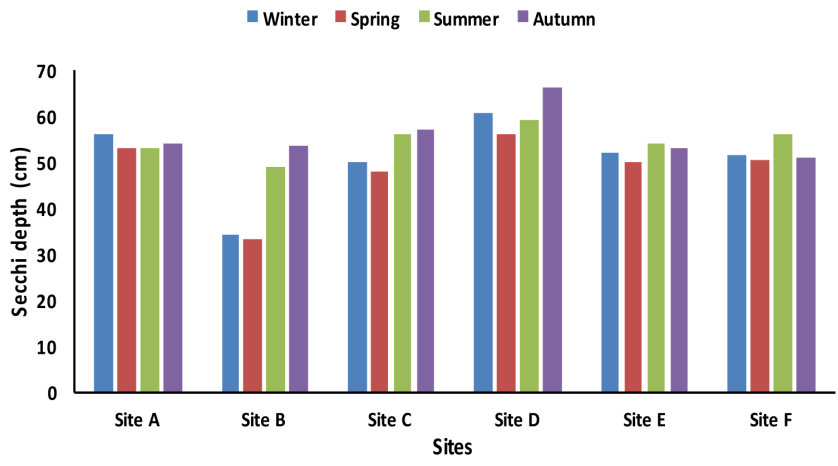

(c)

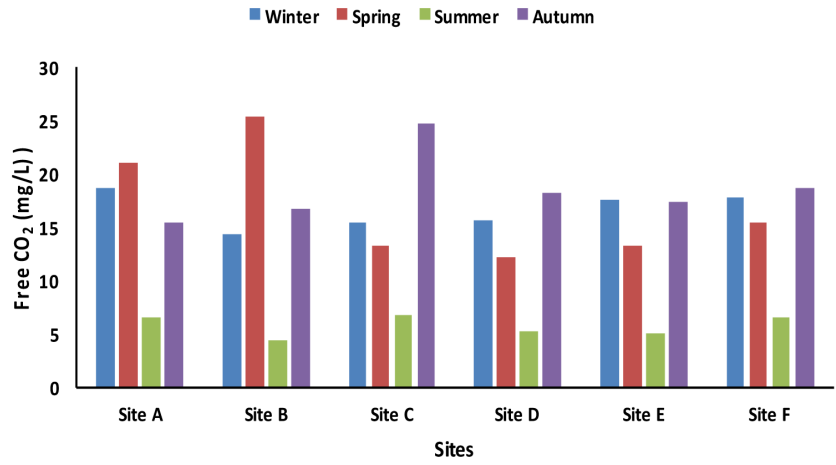

(e)

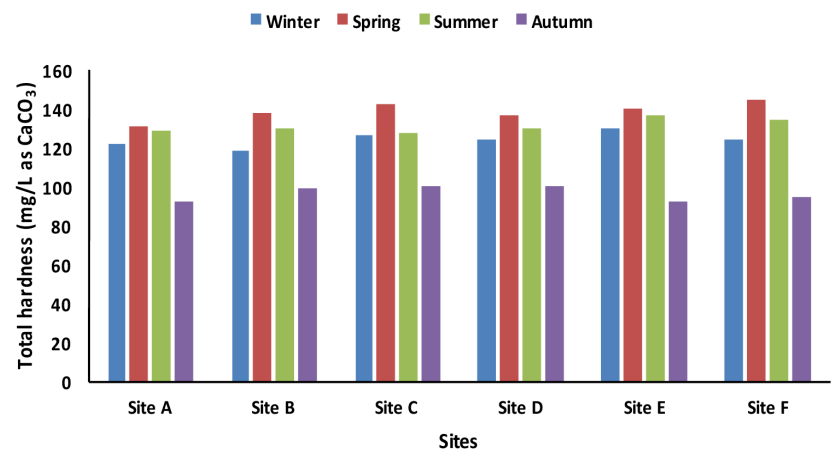

(g)

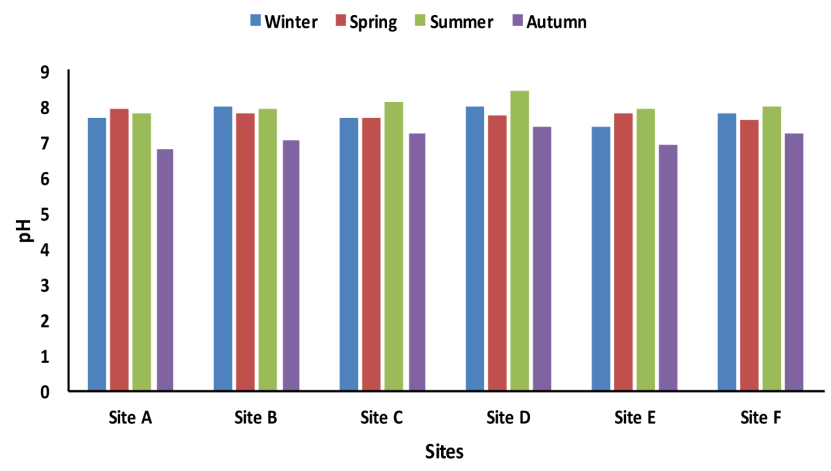

(b)

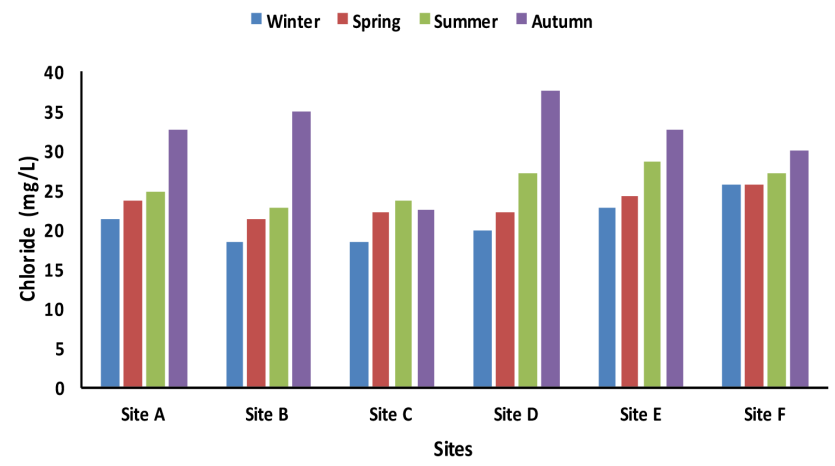

(d)

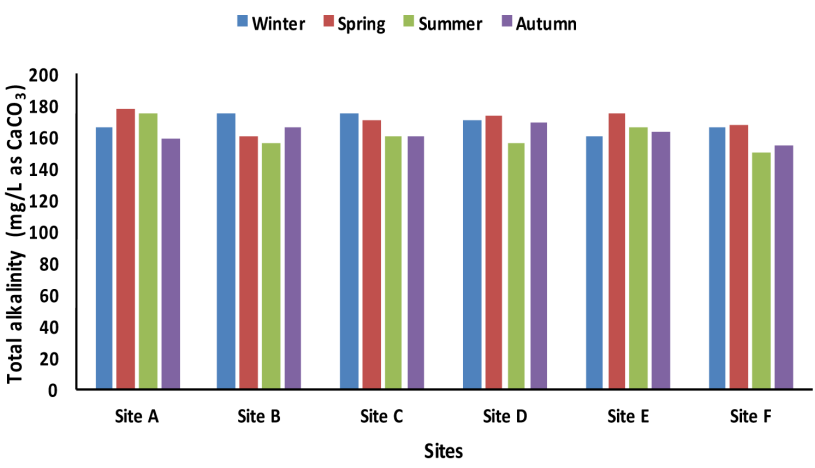

(f)

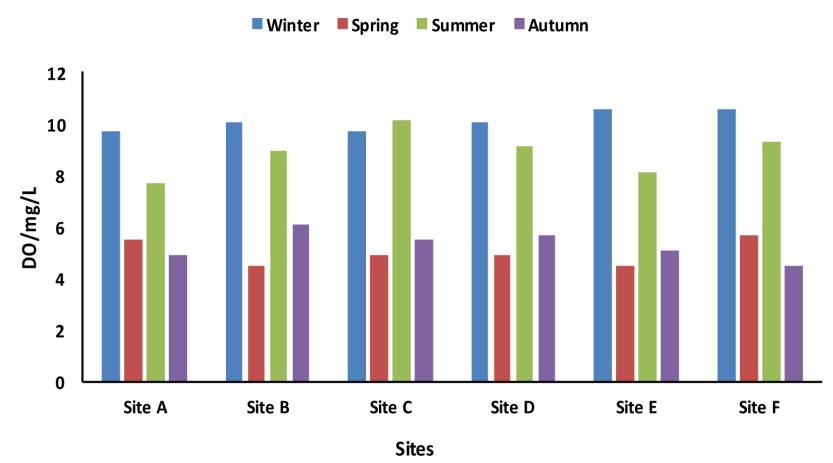

(h)

Figure 2. Seasonal variation of (a) temperature; (b) $\mathrm{pH}$; (c) secchi depth; (d) chloride; (e) free $\mathrm{CO}_{2}$; (f) total alkalinity; (g) total hardness; and (h) DO of Taudaha Lake, Kathmandu, Nepal in 2006. 
The mean annual concentration of chloride was recorded as $25.35 \pm 4.60 \mathrm{mg} / \mathrm{L}$, with the maximum in autumn $(31.7 \pm 5.2 \mathrm{mg} / \mathrm{L})$ and minimum in winter $(21.1 \pm 2.8 \mathrm{mg} / \mathrm{L})$ (Table 1). The concentration of chloride varied significantly $(P<0.001)$ among the sampling seasons (Table 1; Figure 2(d)). The average concentration of free $\mathrm{CO}_{2}$ was recorded to be $14.4 \pm 5.8 \mathrm{mg} / \mathrm{L}$ (Table 1 ). The concentration of free $\mathrm{CO}_{2}$ was significantly different among the seasons $(P<0.001)$, the maximum concentration in autumn $(18.5 \pm 3.3 \mathrm{mg} / \mathrm{L})$, and minimum concentration in summer $(5.8 \pm 1.0 \mathrm{mg} / \mathrm{L})($ Table 1 ; Figure 2(e)). The average total alkalinity was recorded to be $165 \pm 5 \mathrm{mg} / \mathrm{L}$ as $\mathrm{CaCO}_{3}$ throughout the year (Table 1). Even though the maximum concentration of total alkalinity was observed in spring $\left(170.4 \pm 6.2 \mathrm{mg} / \mathrm{L}\right.$ as $\left.\mathrm{CaCO}_{3}\right)$ and minimum concentration was observed in summer $\left(160 \pm 9 \mathrm{mg} / \mathrm{L}\right.$ as $\left.\mathrm{CaCO}_{3}\right)$, there was no significant difference between the seasons $(P=0.35)$ (Table 1; Figure 2(f)).

The average total hardness was recorded to be $122.5 \pm 18.5 \mathrm{mg} / \mathrm{L}$ as $\mathrm{CaCO}_{3}($ Table 1 ). The maximum concentration of total hardness was recorded in spring (138.5 \pm 4.6 $\mathrm{mg} / \mathrm{L}$ as $\left.\mathrm{CaCO}_{3}\right)$ and minimum concentration was recorded in autumn $(96.3 \pm 3.8$ $\mathrm{mg} / \mathrm{L}$ as $\left.\mathrm{CaCO}_{3}\right)$. The concentration of total hardness was significantly different with seasons, which indicated a change in total hardness through the seasons $(P<0.001)$ (Table 1; Figure 2(g)). The average concentration of DO was recorded as $7.31 \pm 2.58$ $\mathrm{mg} / \mathrm{L}$ (Table 1). The maximum concentration of DO was observed during winter $(10.11 \pm 0.31 \mathrm{mg} / \mathrm{L})$ and minimum concentration was recorded during spring (4.96 \pm $0.51 \mathrm{mg} / \mathrm{L})$. DO was significantly varied among seasons $(P<0.001)$ (Table 1; Figure $2(\mathrm{~h}))$.

The average concentration of nitrate was recorded as $0.05 \pm 0.01 \mathrm{mg} / \mathrm{L}$ with the maximum concentration during summer $(0.06 \pm 0.01 \mathrm{mg} / \mathrm{L})$ and minimum during winter $(0.03 \pm 0.01 \mathrm{mg} / \mathrm{L})$ (Table 1$)$. Nitrate was significantly different $(P=0.004)$ with seasons (Table 1; Figure 3(a)). The average concentration of phosphate was recorded as $0.01 \pm 0.04 \mathrm{mg} / \mathrm{L}$ (Table 1 ). The maximum concentration of phosphate was observed during autumn $(0.12 \pm 0.07 \mathrm{mg} / \mathrm{L})$ and minimum concentration was recorded during winter $(0.046 \pm 0.03 \mathrm{mg} / \mathrm{L})$. Phosphate was significantly different $(P=0.02)$ with the seasons (Table 1; Figure $3(\mathrm{~b})$ ). Gross primary productivity was significant $(P=0.003)$ with the sampling seasons, but net primary productivity was not consistent over time $(P=0.36)$ (Table 1$)$. The average gross primary productivity of the lake was observed to be $3.61 \pm 0.06 \mathrm{gC} / \mathrm{m}^{3} /$ day with higher concentration observed during summer (3.92 \pm $0.18 \mathrm{gC} / \mathrm{m}^{3} /$ day $)$ and lower concentration observed during spring $(2.44 \pm 0.67$ $\mathrm{gC} / \mathrm{m}^{3} /$ day) (Table 1 ; Figure $3(\mathrm{c})$ ). The average net primary productivity of the lake was observed as $1.7 \pm 0.21 \mathrm{gC} / \mathrm{m}^{3} /$ day with higher concentration recorded during autumn $\left(2.01 \pm 0.39 \mathrm{gC} / \mathrm{m}^{3} /\right.$ day $)$ and lower concentration observed during spring $1.55 \pm$ $0.39 \mathrm{gC} / \mathrm{m}^{3} /$ day) (Table 1; Figure 3(d)).

\subsection{Macroinvertebrate Communities}

Overall, 2166 individual macroinvertebrates from seven orders and ten families were collected over four sampling seasons from six sites of the lake (Table 2). Macroinverte- 
Winter $\square$ Spring $\backsim$ Summer $\square$ Autumn

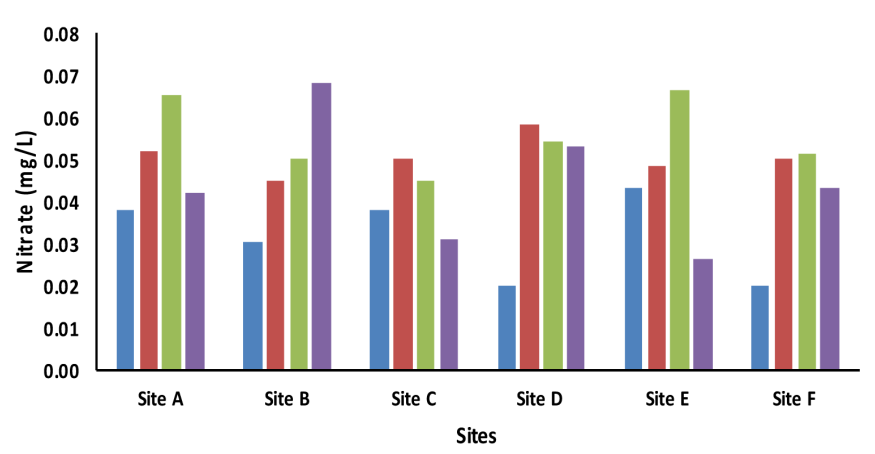

(a)

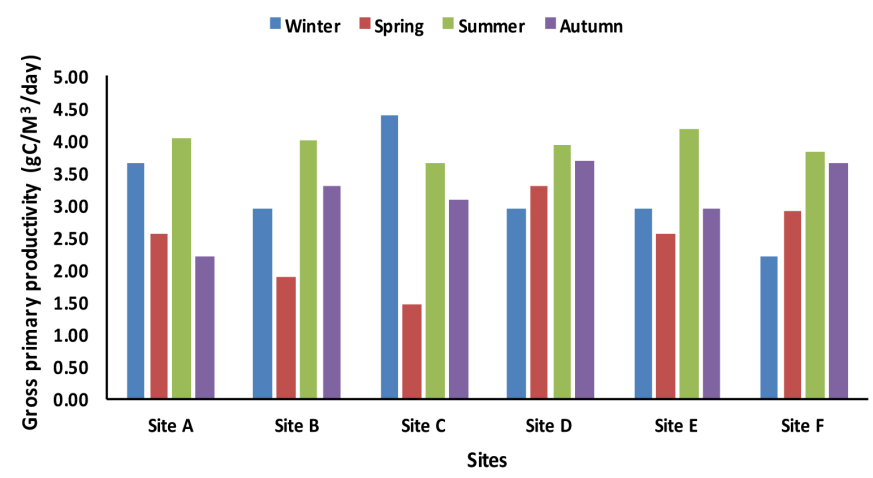

(c)

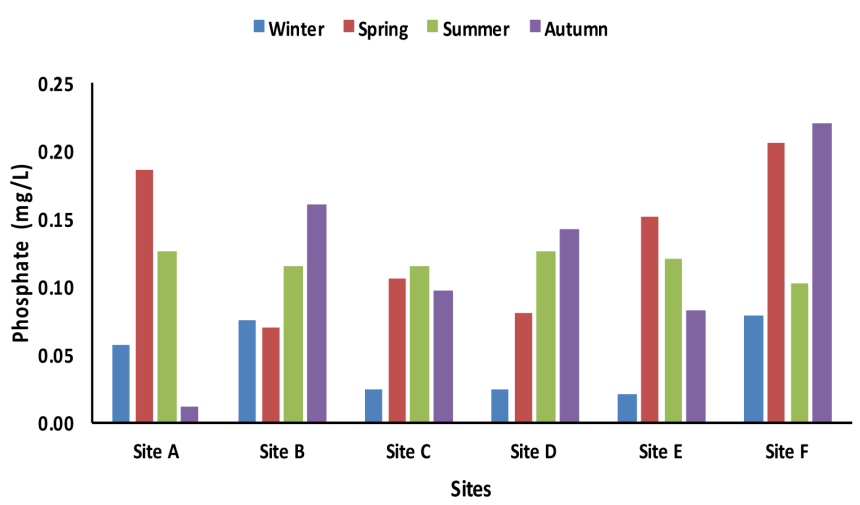

(b)

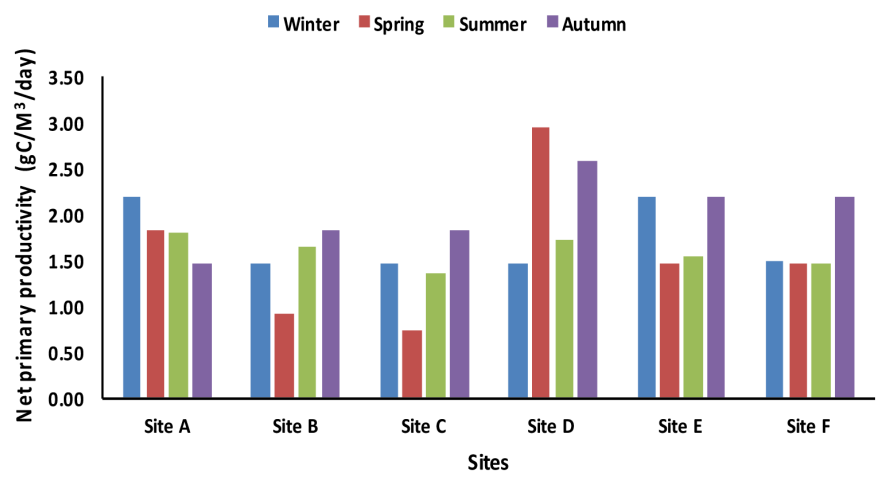

(d)

Figure 3. Seasonal variation of (a) nitrate (b) phosphate (c) gross primary productivity; and (d) net primary productivity of Taudaha Lake, Kathmandu, Nepal in 2006.

Table 2. One-way analysis of macroinvertebrate community indices in Taudaha Lake, Kathmandu, Nepal during the four seasons of 2006.

\begin{tabular}{ccccccc}
\hline \multirow{2}{*}{ Biotic Indices } & \multicolumn{5}{c}{ Seasons } \\
\cline { 2 - 7 } & Winter & Spring & Summer & Autumn & F & $\boldsymbol{P}$ \\
\hline Species Diversity (H') & $0.40 \pm 0.24$ & $0.40 \pm 0.29$ & $0.54 \pm 0.21$ & $0.39 \pm 0.20$ & 0.55 & 0.656 \\
Species Evenness (E) & $0.29 \pm 0.161$ & $0.26 \pm 0.16$ & $0.36 \pm 0.16$ & $0.28 \pm 0.11$ & 0.57 & 0.644 \\
Species Richness (D) & $0.56 \pm 0.18$ & $0.54 \pm 0.24$ & $0.49 \pm 0.07$ & $0.49 \pm 0.11$ & 0.27 & 0.847 \\
\hline
\end{tabular}

brate communities were similar in all four seasons. Chironomidae was the most dominant family, representing $90 \%$ of all macroinvertebrates, while the species of remaining nine families represent only $10 \%$ of total macroinvertebrates (Table 2). The Shannon diversity index $(H)$ value ranged from 0.39 to 0.54 (Table 3 ). Similarly, species evenness $(E)$ ranged between $0.26-0.36$ and species richness $(D)$ ranged between $0.49-0.56$ during the sampling period (Table 3 ). The one-way ANOVA suggested that the macroinvertebrate community-based biotic indices were consistent through the time and not significantly different $(P>0.05)$ among the seasons (Table 3$)$. 
Table 3. Macroinvertebrate community composition and relative abundance in Taudaha Lake, Kathmandu, Nepal during four seasons of 2006.

\begin{tabular}{cccccc}
\hline \multicolumn{2}{c}{ Macroinvertebrate species } & \multicolumn{4}{c}{ Relative abundances } \\
\hline Order & Family & Winter (\%) & Spring (\%) & Summer (\%) & Autumn (\%) \\
\hline Diptera & Chironomidae & 92.45 & 93.68 & 89.22 & 90.76 \\
Diptera & Ceratopogonidae & 0.24 & 0.53 & - & 1.26 \\
Diptera & Limoniidae & - & - & 0.43 & 0.84 \\
Ephemeroptera & Caenidae & 0.94 & 0.53 & 1.15 & 1.05 \\
Ephemeroptera & Baetidae & 1.89 & 1.40 & 2.01 & 1.05 \\
Trichoptera & Hydropsychidae & 0.94 & 0.88 & 3.02 & 1.68 \\
Haplotaxida & Naididae & 0.71 & 0.70 & 1.15 & 0.21 \\
Odonata & Gomphidae & 0.24 & 0.18 & 1.01 & 0.84 \\
Tricladida & Planaridae & 0.94 & 0.70 & 0.72 & 1.68 \\
Arhynchobdellida & Salifidae & 1.65 & 1.40 & 1.29 & 0.63 \\
Total abundance & 424 & 570 & 696 & 476 \\
\hline
\end{tabular}

\section{Discussion}

Taudaha Lake is ecologically and economically significant which provides important habitat and refuge for migratory birds and different species of fishes, and supports the local business through eco-tourism. Water quality of the lake is the major factor that affects the community structure of aquatic species including macroinvertebrates. Temperature is one of the major environmental factors that have a significant effect on the other water quality variables and aquatic species [20] [21]. Seasonal changes in water temperature are directly affected by the air temperature [10]. Similar trends of water temperature variation in Taudaha Lake was observed in the study conducted in 2005 and 2013 [22] [23]. Since Taudaha Lake is a Polymictic Lake [22] with an average depth of $6 \mathrm{~m} \mathrm{[13]} \mathrm{[22],} \mathrm{thermal} \mathrm{stratification} \mathrm{was} \mathrm{not} \mathrm{possible} \mathrm{[24]} \mathrm{[25]} \mathrm{[26].} \mathrm{Organic} \mathrm{and} \mathrm{in-}$ organic particulate matter were important factors that affect the secchi depth of the lake [27]. The lower secchi depth of the lake during spring season was mainly due to the transport of sediments from the agricultural land in the watershed [28]. The lower secchi depth indicated higher total suspended solids (TSS) as well as increased in algal blooms [28] [29]. Similar results with low secchi depth were observed in Taudaha Lake [22], and in Beeshazar lake [20] located in western Nepal.

The higher conductivity observed during summer was possibly due to the agricultural activities, leaching of fertilizers from the cropland [6] [30], and a significant amount of dissolved salts in the lake [31]. Various studies [22] [32] [33] have reported higher lake conductivity during summer, which is a strong indicator of agricultural intensity and its associated impacts. Chloride in water bodies is mainly due to the weathering of sodium chloride $(\mathrm{NaCl})$ containing rocks; however, rainwater can be a significant source of chloride for lakes [10]. In addition to irrigation runoffs from croplands, 
ground water, which is a major source of water input in the lake, was an important contributing factor for the elevated chloride concentration [31]. The values of chloride in all seasons were lower than the WHO proposed drinking water quality criteria [34]. It has been suggested that the concentrations of chloride higher than $200 \mathrm{mg} / \mathrm{L}$ could have significant health effects [31] [35]. The concentration of DO in natural water depends on the physical, chemical, and biochemical activities of in the water body [31] [36]. As expected, the concentration of DO fluctuated during the study seasons. Since the concentration of DO is inversely related to the temperature [10] [36], the current study revealed the increased DO concentration $(10 \mathrm{mg} / \mathrm{L})$ during winter season. The lowest concentration of DO was $\sim 5 \mathrm{mg} / \mathrm{L}$ in spring and autumn seasons, which is sufficient for the survival of most of the fish species in the water body [37] [38].

Change in urban and agricultural land uses alter the consumption and uses of water and sediments causing the elevated concentration of nutrients (nitrogen and phosphorus) in the lakes [10]. Nutrients are present naturally in the environment, however, runoff of fertilizers from the adjacent agricultural croplands and domestic sewage are the major source of nutrients into the lakes [31]. Although the studied area is surrounded by the agricultural croplands and households, the concentration of nutrients $(\mathrm{N} \& \mathrm{P})$ in the lake is below the WHO recommended value [34]. The littoral and riparian zone of the lakecan trap the excessive nutrients and help to maintain nutrients load into the lakes [6] [39]. Nutrients are the major causes of eutrophication in the water bodies [4] [40], but their concentrations were relatively low during the studied period indicating the healthy water quality of the lake [15]. The concentration of nitrate and phosphate in Taudaha lake were lower as compared to the previous studies [23] [41]. Although nutrients are the limiting factors [42] [43], availability of light, temperature, algae, and planktons, also have a significant effect on the primary productivity of the lakes [44] [45]. Both gross and net primary productivity of the lake were relatively low as compared to the productivity of other lakes of the southern and western Nepal [20] [32]. Results of this study indicated the significant positive correlation between net primary productivity and secchi depth (+0.5043), which was also supported by the study conducted in the Oak Lake, South Dakota, U.S.A [45]. The primary productivity usually occurs within $0.5 \mathrm{~m}$ of the lake [45] if not restricted by the higher turbidity and suspended solids, which decrease the light penetration required for photosynthesis [46] [47]. The secchi depth of Taudaha Lake during the study period was $\sim 0.5 \mathrm{~m}$ indicating the higher turbidity due to the larger loading of suspended solids-possibly from the surrounded agricultural croplands [22] which could be a major factor in decreasing light penetration and lowering productivity of the lake [46] [47].

Macroinvertebrates play a critical role in the natural flow of energy and nutrients and are a good indicator of pollution [10]. The community-based indices indicated no differences in the macroinvertebrate structure with the seasons. Most of the literature [48] [49] [50] [51] suggested that the macroinvertebrate assemblages correlate with the increased nutrients and degraded physical habitats. Since the nutrient concentration of the lake was low and habitat degradation was a function of increased nutrients [49] 
[51], the current study does not support the above statement. The species of orders Ephemeroptera and Trichoptera (ET) are generally indicators of less polluted whereas species of orders Hemiptera, Diptera, and some species of Oligochaeta generally indicate the polluted water bodies [9] [10]. The higher abundances (more than 90\%) of species of Diptera in all seasons and lower abundance (less than 5\% in three seasons) of ET taxa indicate degraded habitat and water quality of the lake [49] [52]. Although the abundances of macroinvertebrates indicated degraded water quality, it is important to consider historical background of the lake before using the macroinvertebrates as biological indicators [9].

\section{Conclusion}

Water quality of the Taudaha Lake showed significant temporal variations except for secchi depth and total alkalinity, but the biotic indices did not show any significant differences among seasons. The results indicate the anthropogenic activities (agricultural activities) and rainfall regime as major factors affecting the water quality and biota of the lake. Although most of the water quality of the lake meets WHO guideline for drinking water requirement, the dominance of Chironomidae family indicates the degraded habitat condition of the lake. Overall, this study represents the general water quality parameters and the condition of benthic macroinvertebrates of the lake.

\section{Acknowledgements}

We are thankful to the Central Department of Environmental Science, Tribhuvan University, Kirtipur for providing laboratory facilities. We are also thankful to Dr. Umakant Ray Yadav and Dr. Mohan Bikram Gewali for their valuable guidance and support during the course of this study.

\section{References}

[1] Kalff, J. (2001) Limnology: Inland Water Ecosystem. Prentice Hall, New Jersey.

[2] Downing, J.A., Prairie, Y.T., Cole, J.J., Duarte, C.M., Tranvik, L.J., Striegl, R.G., McDowell, W.H., Kortelainen, P., Caraco, N.F., Melack, J.M. and Middelburg, J.J. (2006) The Global Abundance and Size Distribution of Lakes, Ponds, and Impoundments. Limnology and Oceanography, 51, 2388-2397. https://doi.org/10.4319/lo.2006.51.5.2388

[3] Shiklomanov, I.A. and Rodda, J.C. (2003) World Water Resources at the Beginning of the Twenty-First Century. Cambridge University Press, Cambridge.

[4] Miller, G.T. (2005) Living in the Environment: Principles, Connections, and Solutions. Brooks/Cole Cengage Learning, Belmont, California.

[5] Voshell Jr., J.R. (2011) A Guide to Common Freshwater Invertebrates of North America. The McDonald and Woodward Publishing Company, Granville, Ohio.

[6] Chen, Y., Daniels, M., Reba, M., Bouldin, J., Teague, T.G., Henry, C., Daniel, P., Shrestha, S., Farrelly, J., Frame, D., Busch, D., Radatz, A., Cooley, E., Haggard, B., Hendrix, J. and Miller, D. (2016) Agriculture in the Mississippi River Basin-Effects on Water Quality, Aquatic Biota, and Watershed Conservation. In: Chen, Y., et al., Ed., Fishery Resources, Environment, and Conservation in the Mississippi and Yangtze (Changjiang) River Basins, American Fisheries Society Symposium 84, Bethesda, MD, USA. 
[7] Stewart, P.M., Butcher, J.T. and Swinford, T.O. (2000) Land Use, Habitat, and Water Quality Effects on Macroinvertebrate Communities in Three Watersheds of Lake Michigan Associated Marsh System. Aquatic Ecosystem Health and Management, 3, 179-189. https://doi.org/10.1016/S1463-4988(99)00058-5

[8] Hilsenhoff, W.L. (1987) An Improved Biotic Index of Organic Stream Pollution. Great Lakes Entomologist, 20, 31-39.

[9] Rosarro, B., Marziali, L., Cardoso, A.C., Solimini, A., Free, G. and Giacchini, R. (2007) A Biotic Index Using Benthic Macroinvertebrates for Italian Lakes. Ecological Indicators, 7, 412-429. https://doi.org/10.1016/j.ecolind.2006.04.002

[10] Allan, J.D. and Castillo, M.M. (2007) Stream Ecology: Structure and Function of Running Water. Springer Science Publishers, Dordrecht, Netherlands. https://doi.org/10.1007/978-1-4020-5583-6

[11] Kansanas, P.H., Paasivirta, L. and Vayrynen, T. (1990) Ordination Analysis and Bioindices Based on Zoobenthos Communities Used to Assess Pollution of a Lake in Southern Finland. Hydrobiologia, 202, 153-170. https://doi.org/10.1007/BF00006842

[12] Karn, S.K. and Harada, H. (2001) Surface Water Pollution in Three Urban Territories of Nepal, India, and Bangaldesh. Environmental Management, 28, 483-496. https://doi.org/10.1007/s002670010238

[13] Shrestha, N., Lamsal, A., Regmi, R.K. and Mishra, B.K. (2015) Current Status of Water Environment in Kathmandu Valley, Nepal. Water and Urban Initiative Working Paper Series, $3,1-5$.

[14] Hickel, B. (1973) Phytoplankton in Two Ponds in Kathmandu Valley (Nepal). Internationale Revue der gesamten Hydrobiologie und Hydrographie, 58, 835-842. https://doi.org/10.1002/iroh.19730580605

[15] American Public Health Association (APHA) (2005) Standard Methods for the Examination of Water and Wastewater. Washington DC.

[16] Ward, J.V. (1992) Aquatic Insect Ecology, Vol. 1: Biology and Habitat. John Wiley \& Sons, New York.

[17] Shannon, C.E. (1948) A Mathematical Theory of Communication. Bell System Technical Journal, 27, 379-423. https://doi.org/10.1002/j.1538-7305.1948.tb01338.x

[18] Pielou, C.E. (1966) The Measurement of Biodiversity in Different Types of Biological Collections. Journal of Theoretical Biology, 13, 131-144. https://doi.org/10.1016/0022-5193(66)90013-0

[19] Menhinick, E.F. (1964) A Comparison of Some Species-Individuals Diversity Indices Applied to Samples of Field Insects. Ecology, 45, 859-861. https://doi.org/10.2307/1934933

[20] Niraula, R. (2012) Evaluation of the Limnological Status of Beeshazar Lake, a Ramsar Site in Central Nepal. Journal of Water Resources and Protection, 4, 256-263. https://doi.org/10.4236/jwarp.2012.45028

[21] Abdo, M.H. (2005) Physicochemical Characteristics of Abu za'baal Ponds, Egypt. Egyptian Journal of Aquatic Research, 31, 1-15.

[22] Lacoul, P. and Freedman, B. (2005) Physical and Chemical Limnology of 34 Lentic Water Bodies along Tropical-to-Alpine Altitudinal Gradient in Nepal. International Review of Hydrobiology, 3, 252-276.

[23] Pradhananga, A.R., Shakya, R.K. and Shakya, P.R. (2013) Assessment of Physico-Chemical Parameters of Surface Water Quality of Taudaha Lake of Kathmandu and Their Comparison with Other Global Published Values. Bibechana, 9, 141-150. 
[24] Gorham, E. and Boyce, F.M. (1989) Influence of Lake Surface Area and Depth upon Thermal Stratification and the Depth of the Summer Thermocline. Journal of Great Lake Resources, 15, 233-245. https://doi.org/10.1016/S0380-1330(89)71479-9

[25] Diana, J.S. (1995) Biology and Ecology of Fishes. Biological Sciences Press, Carmel.

[26] Boehrer, B. and Schultze, M. (2008) Stratification of Lakes. Reviews of Geophysics, 46, RG2005. https://doi.org/10.1029/2006rg000210

[27] Thiemann, S. and Kaufmann, H. (2002) Lake Water Quality Monitoring Using Hyperspectral Airborne Data-A Semiempirical Multisensory and Multitemporal Approach for the Mecklenburg Lake District, Germany. Remote Sensing of Environment, 81, 228-237. https://doi.org/10.1016/S0034-4257(01)00345-5

[28] Gregory, S.V., Swanson, F.J., McKee, W.A. and Cummins, K.W. (1991) An Ecosystem Perspective of Riparian Zones. Bioscience, 41, 540-551. https://doi.org/10.2307/1311607

[29] Rothenberger, M.B., Swaffield, T., Calomeni, A.J. and Cabrey, C.D. (2014) Multivariate Analysis of Water Quality and Plankton Assemblages in an Urban Estuary. Estuaries and Coast, 37, 695-711. https://doi.org/10.1007/s12237-013-9714-0

[30] Maret, T.R., Konrad, C.P. and Tranmer, A.W. (2010) Influence of Environmental Factors on Biotic Responses to Nutrients Enrichment in Agricultural Streams. Journal of the American Water Resources, 46, 498-513. https://doi.org/10.1111/j.1752-1688.2010.00430.x

[31] Kazi, T.G., Arain, M.B., Jamali, M.K., Jalbani, N., Afridi, H.I., Sarfraz, R.A., Baig, J.A. and Shah, A.Q. (2009) Assessment of Water Quality of Polluted Lake Using Multivariate Statistical Techniques: A Case Study. Ecotoxicology and Environmental Safety, 72, 301-309. https://doi.org/10.1016/j.ecoenv.2008.02.024

[32] Gautam, B. and Bhattarai, B. (2008) Seasonal Changes in Water Quality Parameters and Sediment Nutrients in Jagadishpur Reservoir, a Ramsar Site in Nepal. Nepal Journal of Science and Technology, 9, 149-156.

[33] Bhatt, H.P., Saund, T.B. and Thapa, J.B. (2012) Status and Threats to Mugger Crocodile Crocodylus palustris Lesson, 1831 at Rani Tal, Shuklaphanta Wildlife Reserve, Nepal. Nepal Journal of Science and Technology, 13, 125-131.

[34] World Health Organization (WHO) (2011) Guidelines for Drinking-Water Quality. 4th Edition, Geneva.

[35] Versari, A., Parpinello, G.P. and Galassi, S. (2002) Chemometric Survey of Italian Bottled Mineral Waters by Means of Their Labelled Physicochemical and Chemical Composition. Journal of Food Composition and Analysis, 15, 251-264. https://doi.org/10.1006/jfca.2002.1058

[36] Masters, G.M. (2003) Introduction to Environmental Engineering and Science. PrenticeHall of India, New Delhi.

[37] Robison, H.W. and Buchanan, T.M. (1988) Fishes of Arkansas. University of Arkansas Press, Fayetteville.

[38] Pfleiger, W.L. (1997) The Fishes of Missouri. 2nd Edition, Missouri Department of Conservation, Jefferson City.

[39] Kaushal, S.S., Likens, G.E., Jaworski, N.A., Pace, M.L., Sides, A.M., Seekell, D., Belt, K.T., Secor, D.H. and Wingate, T.L. (2010) Rising Stream and River Temperature in the United States. Frontiers in Ecology and the Environment, 8, 461-466. https://doi.org/10.1890/090037

[40] Carpenter, S.R., Caraco, N.F., Correll, D.L., Howarth, R.W., Sharpley, A.N. and Smith, V.H. (1998) Nonpoint Pollution of Surface Waters with Phosphorus and Nitrogen. Ecological Applications, 8, 559-568. 
https://doi.org/10.1890/1051-0761(1998)008[0559:NPOSWW]2.0.CO;2

[41] Devkota, S. (2005) Degrading and Disappearing Wetlands: A Study on Natural Lake Taudaha of Kathmandu Valley. MSc Dissertation, Tribhuvan University, Kirtipur.

[42] Smith, V.H., Joye, S.B. and Howarth, R.W. (2006) Eutrophication of Freshwater and Marine Ecosystem. Limnology and Oceanography, 51, 351-355. https://doi.org/10.4319/lo.2006.51.1_part_2.0351

[43] Sterner, R.W. (2008) On the Phosphorus Limitation Paradigm for Lakes. International Review of Hydrobiology, 93, 433-445. https://doi.org/10.1002/iroh.200811068

[44] Golterman, H.L. and de Oude, N.T. (1991) Eutrophication of Lakes, Rivers, and Coastal Seas. In: Hutzinger O., Ed., The Handbook of Environmental Chemistry, Springer-Verlag, Berlin, 79-124. https://doi.org/10.1007/978-3-540-46685-7_3

[45] Kuehl, L.C. and Troelstrup Jr., N.H. (2013) Relationships between Net Primary Production, Water Transparency, Chlorophyll a, and Total Phosphorus in Oak Lake, Brookings County, South Dakota. Proceeding of the South Dakota Academy of Science, 92, 67-78.

[46] Wetzel, R.G. (2001) Limnology: Lake and River Ecosystems. Academic Press, San Diego.

[47] Karlsson, J.P., Bystrom, P., Ask, J., Ask, P., Persson, L. and Jansson, M. (2009) Light Limitation of Nutrient-Poor Lake Ecosystem. Nature, 460, 506-510.

https://doi.org/10.1038/nature08179

[48] Nerbonne, B.A. and Vondracek, B. (2001) Effect of Local Land Use on Physical Habitat Benthic Macroinvertebrates, and Fish in the Whitewater River, Minnesota, USA. Environmental Management, 28, 87-99. https://doi.org/10.1007/s002670010209

[49] Weatherhead, M.A. and James, M.R. (2001) Distribution of Macroinvertebrates in Relation to Physical and Biological Variables in the Littoral Zone of Nine New Zealand Lakes. $\mathrm{Hy}$ drobiologia, 462, 115-129. https://doi.org/10.1023/A:1013178016080

[50] Sawyer, J.A., Stewart, P.M., Mullen, M.M., Simon, T.P. and Bennett, H.H. (2004) Influence of Habitat, Water Quality, and Land Use on Macro-Invertebrate and Fish Assemblages of a Southeastern Coastal Plain Watershed, USA. Aquatic Ecosystem Health and Management, 7, 85-99. https://doi.org/10.1080/14634980490281353

[51] Heatherly, T. and Whiles, M.R. (2007) Relationships between Water Quality, Habitat Quality, and Macroinvertebrate Assemblages in Illinois Streams. Journal of Environmental Quality, 36, 1653-1660. https://doi.org/10.2134/jeq2006.0521

[52] Barbour, M.T., Gerritsen, J., Snyder, B.D. and Stribling, J.B. (1999) Rapid Bioassessment Protocols for Use in Streams and Wadeable Rivers: Periphyton, Benthic Macroinvertebrates and Fish. 2nd Edition, Report EPA 841-B-99-002, US Environmental Protection Agency, Office of Water, Washington DC. 
Submit or recommend next manuscript to SCIRP and we will provide best service for you:

Accepting pre-submission inquiries through Email, Facebook, LinkedIn, Twitter, etc. A wide selection of journals (inclusive of 9 subjects, more than 200 journals)

Providing 24-hour high-quality service

User-friendly online submission system

Fair and swift peer-review system

Efficient typesetting and proofreading procedure

Display of the result of downloads and visits, as well as the number of cited articles

Maximum dissemination of your research work

Submit your manuscript at: http://papersubmission.scirp.org/

Or contact jwarp@scirp.org 